\title{
The Most Persuasive Frankfurt Example, and What It Shows: Or Why Determinism Is Not the Greatest Threat to Moral Responsibility
}

\author{
Larry Alexander \\ University of San Diego School of Law, San Diego, USA \\ Email: larrya@sandiego.edu
}

Received 8 March 2014; revised 8 April 2014; accepted 15 April 2014

Copyright (c) 2014 by author and Scientific Research Publishing Inc. This work is licensed under the Creative Commons Attribution International License (CC BY). http://creativecommons.org/licenses/by/4.0/ (c) (i) Open Access

\begin{abstract}
In this paper I argue that even if the Principle of Alternative Possibilities (PAP) is satisfied, moral responsibility is more seriously threatened if the Principle of Alternative Possible Reasons (PAPR) is not satisfied. Nor, I argue, is it clear how it could be satisfied. Finally, I suggest that not only moral responsibility, but also normativity itself, is threatened by the failure to satisfy PAPR.
\end{abstract}

Keywords

Libertarian; Moral Responsibility; Normativity; Reasons

\section{The Set Up}

Imagine that $\mathrm{Al}$ is libertarian free- - that is, free in whatever sense libertarians demand for moral responsibility. $\mathrm{Al}$ can choose to act $\mathrm{X}$ or act $\sim \mathrm{X}$, and the laws of nature are consistent with his doing either.

$\mathrm{Al}$ is rationally and morally appraisable only if he chooses $\mathrm{X}$ or $\sim \mathrm{X}$ for a reason (even if his reason is merely to be whimsical in choosing). Al will do $\mathrm{X}$ only if a reason for doing $\mathrm{X}$ presents itself to him just prior to the moment of choice that seems weightier to him than any reason he perceives for doing $\sim X$. And suppose such a reason to $\mathrm{X}$ - call it $\mathrm{R}$ - will only occur to $\mathrm{Al}$ if he attends to, say, the evening news, which will in turn lead him to think of tomorrow's agenda at the office, which will in turn lead him to think of R. And suppose, finally, that a Frankurtian counterfactual intervenor-Ivan — knows the grooves of thought in Al's mind, wants Al to do X, and can intervene through a Frankfurtian device so that if $\mathrm{Al}$ attends to the evening news, Ivan will push a button that blocks Al's perceiving R (Frankfurt, 1969). 
But suppose $\mathrm{Al}$ never attends to the evening news, thus never thinks about tomorrow's agenda, and thus never thinks of R. Not thinking of R, Al does $\sim \mathrm{X}$. Ivan did not have to intervene to achieve this result (The example is in many respects similar to so-called "buffer cases") (Hunt, 2005).

\section{The Analysis}

Does this Frankfurtian case show that the Principle of Alternative Possibilities (PAP) is false? No. It shows that even if PAP is necessary for moral responsibility, it is surely not sufficient for it. Al had alternative possibilities in terms of action. The laws of nature did not rule out $\mathrm{X}$ or $\sim \mathrm{X}$. Al freely chose $\sim \mathrm{X}$. But was Al morally responsible for choosing $\sim \mathrm{X}$ despite his having freely chosen it?

What seems significant is the utter irrelevance to that question of Ivan's intervening. For if $\mathrm{Al}$ had attended to the evening news, and Ivan had intervened, what in terms of Al's responsibility for doing $\sim \mathrm{X}$ would have changed? In other words, if Ivan had intervened to reroute Al's thought processes, and if this intervention would have rendered $\mathrm{Al}$ nonresponsible for doing $\sim \mathrm{X}$, why would whatever did occur in $\mathrm{Al}$ 's brain that caused him not to attend to the evening news not also deprive $\mathrm{Al}$ of responsibility for Xing? For the actual cause in Al's brain was as beyond Al's voluntary control as Ivan's intervention would have been.

What is not satisfied in this scenario is what I shall call the Principle of Alternative Possible Reasons (and their weights) - PAPR. The reasons for action that present themselves to $\mathrm{Al}$ and to us - and their associated weights - are not under our control, even if the actions they direct us to take are. It makes no sense to say we can choose which and how weighty the reasons are that we perceive. Reasons, and beliefs in general, come to us unbidden. It makes no sense to say $\mathrm{Al}$ should have thought of $\mathrm{R}$, for he would need a reason-and that would be $\mathrm{R}$ itself-to think of R. So even if Al were completely free to choose $\mathrm{X}$ or $\sim \mathrm{X}$, he was not free to choose them for reasons that did not occur to him.

(Even if the reasons that occur to $\mathrm{Al}$ are not deterministically generated, $\mathrm{Al}$ still cannot be deemed responsible for which reasons [and their weights] appear to him (Franklin, 2011). Indeed, indeterminism just makes how such reasons appear to the agent a matter of occurrent luck rather than, as with determinism, causal luck (Schlasser, 2014)).

Nor can I see the relevance of whether Al's "mechanism" for assessing reasons and their weights is a generally reliable one (Fisher \& Ravizza, 1998). What seems crucial for moral responsibility is not whether Al would generally think of $\mathrm{R}$ but why $\mathrm{Al}$ did not do so on the occasion in question. A mechanism that is generally reliable but that breaks down at a crucial moment, whether it be a mechanism of reasons responsiveness or an automobile, is a defective mechanism.

PAP may be a valid requirement of moral responsibility for acts. But because the rational and moral appraisability of acts turns on the reasons for which they are taken, PAPR is also necessary; and it is difficult to see how it can be satisfied.

Can one reject PAPR? Can one argue that one is responsible for what reasons occur to him and how weighty they appear even if he has no direct control over how reasons present themselves to him? Again, it seems bootless to demand that a person reject bad reasons for acting even if they appear to him to be good reasons. For what reasons does he occurrently have for rejecting these bad reasons? He has, in Fischer and Ravizza's terminology, a faulty reasons mechanism. If one misses an appointment because one's car won't start, it is irrelevant to one's responsibility for the missed appointment that the car starts fine on most occasions.

As I see it, then, this is where the problem of moral responsibility lies. It does not lie exclusively in whether determinism is true. For as many have pointed out, indeterminism at the point of choice seems to make our choosing correctly a matter of chance, and therefore makes our choice as much beyond our ultimate control as would determinism.

The problem is that even if somehow our choices are free in whatever sense a libertarian demands, those choices cannot be morally assessable apart from the reasons on which those choices are based. And that means that we must have ultimate direct control over how the reasons and their weights appear to us, control at the moment of choice. If the reasons for $\sim \mathrm{X}$ that present themselves to $\mathrm{Al}$ at the moment of choice appear stronger to him than the reasons for $\mathrm{X}$, then is $\mathrm{Al}$ morally responsible for choosing $\sim \mathrm{X}$ even if he was otherwise free to choose $\mathrm{X}$ ? If he had chosen $\mathrm{X}$, he would have chosen against what appeared to him to be the stronger reasons, which would have made his choice an irrational one.

So it seems that for $\mathrm{Al}$ to be morally responsible for choosing $\sim \mathrm{X}$, he must have been able to see that the rea- 
sons favored $\mathrm{X}$ at the very same time he perceived them to favor $\sim X$. Determinism and indeterminism are beside the point because although determinism guarantees that this condition will not be satisfied, indeterminism will not satisfy it either.

What would make the choice a morally responsible one is satisfaction of PAPR. And satisfaction of PAPR would require that holding all of Al's psychology constant, at the moment of choice $\mathrm{Al}$ can see that the reasons favoring $\mathrm{X}$ outweigh those favoring $\sim \mathrm{X}$. That is, the claim would have to be that even if we have no occurrent control over our factual beliefs - they come to us unbidden and from the inside always seem reasonable-we do have occurrent control over our reasons and their weights. That is a tall order; and although we do believe we have such control and therefore hold ourselves and others responsible for assessments of reasons and their weights, we lack a good account of how such control is possible.

(Determinism would appear to be fatal to control over how reasons appear to us (List, 2014; Arneson, 2003). But note that indeterminism in how reasons present themselves to us would be as fatal to this control as would determinism).

In other words, we lack a good account of how a reason that appears to us as strong is one that we can at the very same time see is weak, and vice versa. We cannot, I submit, see that a belief that presents itself as true we can simultaneously see to be false. Is it different for reasons and their weights?

\section{The Implications}

Finally, let me say a word about the implications of this threat to moral responsibility for assessments of reasons. If we are not responsible for how reasons and their weights appear to us at the time of choice, then I cannot see how we can be morally or prudentially responsible for the actions that we choose, even if we are causally responsible for them (One possibility that remains is that we are responsible only when we act akratically, i.e., contrary to our own assessment of which act is recommended by the balance of reasons). Now, some are not troubled by that. For them, all that would be entailed by jettisoning moral and prudential responsibility would be elimination of the reactive attitudes of blame, indignation, and guilt and the notion of desert that undergirds retributive punishment (Pereboom, 2001; Smilansky, 2000; Vilhauer, 2012).

I believe, however, that the threat is much greater (as if the threat to our reactive attitudes and desert-based punishment were not worrisome enough). For I believe all of normativity is threatened. Whatever one ought or ought not to do, believe, etc. will reduce to will or will not do, believe, etc., and normativity will have vanished.

\section{References}

Arneson, R. (2003). The Smart Theory of Moral Responsibility. In S. Olsaretti (Ed.), Desert and Justice (pp. 233-58). Oxford; New York: Oxford University Press.

Fisher, J. M., \& Ravizza, M. (1998). Responsibility and Control: A Theory of Moral Responsibility. Cambridge; New York: Cambridge University Press. http://dx.doi.org/10.1017/CBO9780511814594

Frankfurt, H. (1969). Alternate Possibilities and Moral Responsibility. Journal of Philosophy, 86, 829-839. http://dx.doi.org/10.2307/2023833

Franklin, C. E. (2011). Farewell to the Luck (and Mind) Argument. Philosophical Studies, 156, 199-230. http://dx.doi.org/10.1007/s11098-010-9583-3

Hunt, D. (2005). Moral Responsibility and Buffered Alternatives. Midwest Studies in Philosophy, 29, 126-145. http://dx.doi.org/10.1111/j.1475-4975.2005.00109.x

List, C. (2014). Free Will, Determinism, and the Possibility of Doing Otherwise. Nous, 48, 156-178. http://dx.doi.org/10.1111/nous.12019

Pereboom, D. (2001). Living Without Free Will. Cambridge; New York: Cambridge University Press. http://dx.doi.org/10.1017/CBO9780511498824

Schlasser, M. E. (2014). The Luck Argument against Event-Causal Libertarianism: It Is Here to Stay. Philosophical Studies, 167, 375-385. http://dx.doi.org/10.1007/s11098-013-0102-1

Smilansky, S. (2000). Free Will and Illusion. Oxford; New York: Oxford University Press.

Vilhauer, B. (2012). Taking Free Will Skepticism Seriously. Philosophical Quarterly, 62, 833-852.

http://dx.doi.org/10.1111/j.1467-9213.2012.00077.x 